\title{
ФОРМИРОВАНИЕ НРАВСТВЕННЫХ ПРЕДСТАВЛЕНИЙ У СТАРШИХ ДОШКОЛЬНИКОВ В ИГРОВОЙ ДЕЯТЕЛЬНОСТИ
}

\author{
Вольнягина Дианна Эмировна \\ МАДОУ «Детский сад №21 «Гномик»
}

\begin{abstract}
Аннотация: Современное образование все больше заинтересовано в нравственном воспитании, начало которого закладывается еще в дошкольном периоде. Важный этап развития нравственных представлений приходится на старший дошкольный возраст, когда ребенок уже может самостоятельно оценить свой поступок, при этом не имеет полной сформированной картины поведенческой нормы. Именно поэтому необходимо как можно больше работать в выстраивании и формировании нравственных представлений у старших дошкольников, а также позволять на практике проявлять их в процессе игровой деятельности. Это позволит выработать привычку правильного поведения, которая со временем станет нормой.
\end{abstract}

Ключевые слова: нравственное развитие, нравственные представления, игровая деятельность.

\section{FORMATION OF MORAL IDEAS IN OLDER PRESCHOOLERS IN PLAY ACTIVITIES}

\begin{abstract}
Modern education is increasingly interested in moral education, the beginning of which is laid in the preschool period. An important stage in the development of moral ideas falls on the senior preschool age, when the child can already independently evaluate his act, while he does not have a fully formed picture of the behavioral norm. That is why it is necessary to work as much as possible in building and forming moral ideas among older preschoolers, as well as to allow them to be shown in practice in the process of playing activities. This will allow you to develop the habit of correct behavior, which will eventually become the norm.
\end{abstract}

Key words: moral development, moral ideas, game activity.

Нравственность является одним из наиболее главных качеств личности, которая направлена на формирование правильных ценностей человека, ответственности за свои поступки, а также порядочности и честности. В 
современном мире нравственность имеет все большую актуальность, и ее необходимо прививать и развивать с раннего возраста, когда ребенок уже может самостоятельно давать оценку своим действиям. Это подтверждается социологическими данными, представленными в работах Юревича А.В. Согласно исследованиям, количественно оцененное нравственное состояние современного российского общества обнаруживает положительную динамику с 2008 г., при этом важно отметить отрицательные показатели отличия в абсолютном значении соответствующего показателя 1990 г.

Оптимальным возрастом для развития и формирования нравственных представлений может быть признан старший дошкольный возраст. Для эффективности работы со старшими дошкольниками необходимо выбрать оптимальные методы работы. Игровой метод обучения является наиболее воспринимаемой формой работы с детьми, так как они интересны и привлекают внимание.

Сластенин В.А. в своих работах выделяет понятие о нравственных качествах личности, которые выступают как постоянные свойства личности, проявляющиеся во всех ситуациях, связанных со стремлением ребенка следовать нравственным нормам. Данное мнение является верным, при этом появляется необходимость формирования данных нравственных качеств, что происходит через нравственные представления.

Нравственные представления - это обобщенный образ, форма знания о нравственных нормах, критериях должного, правильного и истинного отношения к себе, к другим людям и миру.

В дошкольный период основной целью нравственности является способность видеть разницу между правильными и неправильными намерениями, мыслями, поступками и поведением. Нравственность является основой воспитательной работы и выступает главной целью в данном процессе. Нравственное воспитание имеет несколько этапов развития, которые начинаются в младенчестве и заканчиваются уже в старшем, взрослом возрасте.

Рассмотрим аспекты развития нравственных представлений у детей в дошкольном возрасте. Дошкольный возраст - период, когда у ребенка закладывается основа умений, знаний, навыков, формируется социальное поведение, которое позволяет выстраивать общую модель поведения. Уже в этом возрасте маленький ребенок становится личностью: со стадии индивида он переходит на этап индивидуальности с присущими только ему привычками, 
наклонностями, способностями, задатками и возможностями, при этом формируются и его ценности и правила поведения, которые напрямую зависят от нравственных качеств ребенка.

В контексте данной работы будет более подробно рассмотрен возраст 5-6 лет, который также именуется как старший дошкольный возраст. Данный возраст отличается особенностью активного познания окружающего мира, изучения процесса общения и выстраивания взаимоотношений между людьми, но также определяет способность на получение определённых знаний.

Далее рассмотрим особенности старшего дошкольного возраста, базой которого является способность ребенка к самостоятельному регулированию своего поведения. Дети, не отвлекаясь на более интересные дела, могут доводить до конца малопривлекательную работу (убирать игрушки, наводить порядок в комнате и т. п.). Это становится возможным благодаря осознанию детьми общепринятых норм и правил поведения и обязательности их выполнения.

Также отдельное внимание ребенка выделяется на самопознание, так в возрасте 5 лет ребенок уже способен дать оценку себе и своим действиям, определить свои качества, а также назвать те качества, которыми бы он хотел обладать. Но поскольку этот процесс только начинается, ребенок не имеет отдельно взятого представления о том, каким он должен быть, поэтому он обычно хочет быть похожим на героев сказок, фильмов или знакомых людей.

Также в 5 лет ребенок готов к восприятию учебной информации, при условии, что она является важной и интересной, исходя из этого следует, что игровые методы обучения наиболее привлекательны и эффективны в работе с детьми данного возраста.

В данном возрасте высокую важность приобретает установление контактов со сверстниками, взаимная оценка и принятие ребенка в коллективе. При оценке поступков сверстников дети часто категоричны и требовательны, при этом в отношении собственного поведения, как правило, более снисходительны и недостаточно объективны. Совокупность представленных факторов развития в старшем дошкольном возрасте отражает необходимость нравственного воспитания и представлений, так как именно это и является основой развития и возможности дальнейшего взаимодействия в обществе.

Дети старшего дошкольного возраста наиболее восприимчивы к активной деятельности, проходящей в игровом виде, где задействовано большое 
количество людей. Кроме того, это способствует всестороннему развитию каждого ребенка, а также повышению уровня познавательного интереса во всех областях.

Рассмотрим основные функции, которые выполняют игры в процессе обучения старших дошкольников.

Первая и наиболее важная - это стимулирующая функция, которая формирует познавательный интерес, а также вызывает желание участвовать в процессе игровой деятельности. Данная функция занимает лидирующую позицию и направлена на более полное включение детей в процесс воспитания.

Вторая функция - коммуникативная, является побудителем желания отстаивать свою точку зрения, вести диалоги, а также просто обмениваться мнениями. Данная функция позволяет ребенку получить опыт выстраивания взаимоотношений, которые должны основываться на нравственных представлениях.

Третья функция направлена на социализацию учащихся, при которых они могут учитывать, что наиболее важно для их заинтересованности.

По характеру игровой методики игры можно разделить на:

- предметные;

- сюжетные;

- ролевые;

- деловые;

- имитационные;

- игры-драматизации.

Выбирая игровую методику, необходимо учитывать возрастные особенности дошкольников, их уровень знаний, а также уровень восприимчивости.

Отсюда следует, что формирование нравственных представлений в старшем дошкольном возрасте необходимо проводить через игровые методы обучения в коллективной работе. Результатом получения нравственных представлений у ребенка является появление и утверждение в личности определенного набора нравственных качеств, которые могут проявляться в процессе коммуникации. Сформированность и адаптированность нравственных качеств у ребёнка отражает меньший уровень отклонений от принятых в обществе моральных устоев. Такое поведение в обществе будет оцениваться как высокий уровень нравственности. 
Выделим основные результаты, которые можно получить в процессе игровой деятельности, отражающие нравственные представления ребёнка: дружеские взаимоотношения в коллективе, умение выстраивать договорённости, взаимопомощь, уважительное отношение к окружающим и другие. Данные проявления нравственного поведения можно представить как индикатор сформированности нравственного представления ребёнка.

Игра способствует переосмыслению и позволяет на опыте испытать нравственные представления. Так ребёнок осваивается и подстраивается под желания окружающих, учится находить оптимальный выход из сложившихся ситуаций, выстраивает взаимоотношения, сдерживает негативные эмоции и преодолевает трудности.

Отсюда следует, что игра позволяет практическим путем проверить, доказать или опровергнуть теоретические представления ребенка о нравственности, тем самым формируя более полную картину поведения. Такой практический опыт способствует развитию следующих качеств ребенка: общности, эмпатии, самооценки. Все это служит фундаментом для выстраивания коммуникаций в обществе в рамках заданного поведения и прививает такие качества как: сочувствие, взаимопонимание, сопереживание, терпимость и другие.

Только практический опыт позволяет выстраивать взаимосвязь нравственного сознания и поведения, так как ребенок в процессе игры встает перед выбором морального поведения. После выбора правильной модели поведения, когда ребенок отдает предпочтение правильному поступку, а не своей минутной прихоти, формируется привычка нравственного поведения, которая из игры переходит в настоящую жизнь.

\section{Вывод}

Рассмотрев особенности формирования нравственных представлений можно заключить, что оно происходит в течение взросления человека, но при этом оптимальным возрастом активного обучения является старший дошкольный. Так как ребенок данного возраста в силу своих психологических особенностей наиболее восприимчив к игровой деятельности, обучение необходимо проводить, используя игровые методы работы. Игра позволяет ребенку опытным путем проверять свои нравственные представления и получать обратную реакцию как от детей, так и от воспитателя, который контролирует данный процесс. Впоследствии такое подведение формирует нравственное поведение ребенка, которое он использует в повседневной жизни. 


\section{Список литературы}

1. Гонина, О.О. Психология дошкольного возраста : учебник и практикум для среднего профессионального образования / О.О. Гонина. - 2-е изд., испр. и доп. - Москва : Издательство Юрайт, 2018. - 425 с. (Профессиональное образование). — ISBN 978-5-534-08615-7. - Текст : электронный // Образовательная платформа Юрайт [сайт]. - URL: https://urait.ru/bcode/425863 (дата обращения: 10.09.2021).

2. Учеб. пособие для студ. высш. пед. учеб. заведений / В.А. Сластенин, И.Ф. Исаев, Е.Н. Шиянов; Под ред. В.А. Сластенина. - М.: Издательский центр "Академия", 2002 - 576 с.

3. Юревич Андрей Владиславович Эмпирические оценки нравственного состояния современного российского общества // Ярославский педагогический вестник. 2018. №4. URL: https://cyberleninka.ru/article/n/empiricheskie-otsenkinravstvennogo-sostoyaniya-sovremennogo-rossiyskogo-obschestva (дата обращения: 10.09.2021).

4. Якименко Валентина Анатольевна Сущность и функции игры в дошкольном образовании // Калининградский вестник образования. 2020. №1. URL: $\quad$ https://cyberleninka.ru/article/n/suschnost-i-funktsii-igry-v-doshkolnomobrazovanii (дата обращения: 10.09.2021). 